\title{
Educational actions on first aid for early childhood education teachers: a quasi-experimental study*
}

\author{
Ações educativas sobre primeiros socorros com professores da educação infantil: \\ estudo quase-experimental \\ Acciones educativas sobre primeros auxilios con profesores de educación infantil: \\ estudio casi experimental
}

How to cite this article:

Ilha AG, Cogo SB, Ramos TK, Andolhe R, Badke MR, Colussi G. Educational actions on first aid for early childhood education teachers: a quasi-experimental study. Rev Esc Enferm USP. 2021;55:e20210025. DOI: http://dx.doi.org/10.1590/1980-220X-REEUSP-2021-0025

\section{Aline Gomes Ilha ${ }^{1}$ \\ Silvana Bastos Cogo ${ }^{1}$ \\ Tierle Kosloski Ramos ${ }^{1}$ \\ Rafaela Andolhe ${ }^{1}$ \\ Marcio Rossato Badke ${ }^{1}$ \\ Giovana Colussi ${ }^{1}$}

* Extracted from the Term Paper "Atuação dos professores da educação infantil em situações de primeiros socorros", Universidade Federal de Santa Maria, 2018.

${ }^{1}$ Universidade Federal de Santa Maria,

Departamento de Enfermagem,

Santa Maria, RS, Brazil.

\begin{abstract}
Objective: To assess the early childhood education teachers' knowledge about first aid before and after the participation in an educational action. Method: Quantitative research with a quasi-experimental pre- and post-test design, carried out with 45 teachers from four early childhood education schools. For data collection, an instrument with questions regarding the characterization of the participants and knowledge about first aid was used. Data were analyzed through statistical techniques, using the Shapiro Wilk and Wilcoxon tests. Results: There was an increase in the number of correct answers to the questions and improvement regarding grades, with an increase in the score from pre- to post-test by 5.17 points and with a significant comparison of sums. Conclusion: Carrying out educational actions on first aid increases the knowledge of early childhood education teachers on the subject and the nurses' role as health educators is highlighted.
\end{abstract}

DESCRIPTORS

First Aid; Child Rearing; Nursing; Health Education. 


\section{INTRODUCTION}

Childhood is characterized by different stages of development. One of these phases is early childhood, which includes children up to six years of age. In this age group, mental, emotional, and social development takes place through positive or negative experiences lived and shared ${ }^{(1)}$. With regard to education, according to the Brazilian Common Core Curriculum of 2018, children in this age group belong to early childhood education, which teaches children from zero to five years old ${ }^{(2)}$.

According to data from the Mortality Information System, in 2018, external causes were the mainly accountable to the occurrence of deaths of children aged zero to nine years in Brazil, namely: transport accidents (19.86\%), followed by drowning $(19.76 \%)$ and other respiratory risks ${ }^{(3)}$. External causes are trauma, injuries, or any other harm to health, whether intentional or not, of sudden occurrence, and as an immediate consequence of violence or another exogenous cause, which may be an accident ${ }^{(4)}$. Among the accidents, there are those resulting from preventable causes, which are conceptualized as being predictable and preventable accidents. These are common in childhood, as children develop through experiences, among which falls are highlighted as the most frequent type, followed by contact with objects, cuts, and burns ${ }^{(5)}$.

To minimize childhood accident rates, in 2001 the Ministry of Health (MS) approved the National Policy for the Reduction of Morbidity and Mortality from Accidents and Violence, which establishes guidelines and institutional responsibilities contemplating and valuing measures inherent to health promotion and accident prevention ${ }^{(6)}$. With the same objective, in 2007 the Health at School Program $(P S E)$ was created, which integrates and articulates education and health to contribute to the comprehensive training of students through actions for health promotion, prevention and care, facing the vulnerabilities that hinder the full development of children and young people of the public school network ${ }^{(7)}$. Following this, in 2015 the MS instituted the National Policy for Comprehensive Child Health Care (PNAISC), which aims to promote and protect children's health through comprehensive and integrated care and care from pregnancy to nine years of age, with special attention to early childhood, aiming at reducing morbidity and mortality and offering an environment that facilitates life and development ${ }^{(8)}$.

When considering the possibility of accidents, knowledge about first aid to provide quick and effective care for children will influence their recovery or health worsening. Thus, first aid refers to the first care provided to the person who is injured and can be performed by any citizen who has the knowledge of basic techniques ${ }^{(9)}$.

In early childhood education, children are constantly finding new objects, and this exposes them to risky situations, generally leading to accidents. Therefore, the teacher needs to provide the first care and refer the child to the medical service, when necessary, since he/she is responsible for the child at that time. Thus, the teacher shall have basic notions of first aid to take action in these situations ${ }^{(10)}$.

Considering this need experienced by teachers, the importance of formal and continuous training on first aid is highlighted ${ }^{(11-12)}$. In studies, it is noted that teachers show they are aware of their lack of preparation to provide first aid and of the importance of the victim receiving adequate care $^{(12-14)}$. In this perspective, Law No. 13.722, of October 4, 2018, was created to make training of teachers and employees of public and private basic education institutions and of child recreation facilities on first aid basics mandatory ${ }^{(15)}$. It should be noted that teachers have an important and growing role in health promotion and accident prevention among children ${ }^{(16)}$.

Consequently, it is evident that the school environment is a privileged place for health education ${ }^{(17)}$ and nurses gain a prominent role because, according to their professional practice, education aimed at improving the population's health status is one of their functions ${ }^{(18)}$. This professional is trained, in theory and practice, to contribute as an educator, guiding and mobilizing society about health promotion and prevention $^{(19)}$. Thus, it is important to spread knowledge on first aid to children's teachers, as educators show to be laypersons in what regards initial care of school accidents, although they are interested in learning ${ }^{(17)}$. The search carried out points to the need for activities related to this practice.

Accordingly, given the rates related to accidents in childhood, which often occur in the school settings, as well as the unpreparedness of early childhood education teachers to act in situations involving first aid, the research question is: does an educational action improve the knowledge of early childhood teachers about first aid? And the hypotheses are: $\mathrm{HO}$ - The educational action did not change the knowledge of early childhood education teachers about first aid in the school environment; H1 - The educational action changed the knowledge of early childhood education teachers about first aid in the school environment. Therefore, our objective is to assess the early childhood education teachers' knowledge about first aid before and after participation in the educational action.

\section{METHOD}

\section{Type Of Study}

This is a quantitative research with a quasi-experimental pre- and post-test design. The research took place in the four Municipal Schools of Early Childhood Education (EMEIs) in an inland city of Rio Grande do Sul (RS), referenced by the Municipal Department of Education as those with the largest number of teachers.

\section{Population}

The research participants were municipal teachers working in early childhood education. The inclusion criterion adopted was to have an undergraduate degree for teaching or Pedagogy, and the exclusion criteria were to be on vacation, leave of any other nature during the period of 
data collection, or to be absent from any of the stages of the study (pre- test, educational action, post-test). Thus, seven participants were excluded from the research; of these, six due to absence in one of the stages of data collection and one for being on a maternity leave.

\section{Data Collection}

Data collection took place in three stages: application of the pre-test (diagnosis of reality), educational action (intervention when facing the demands emerging in the previous stage), and post-test (evaluation of knowledge acquisition). All stages were carried out throughout 2018 and 2019 , with an interval of one week between one stage and another. All steps took place in classrooms provided by the schools, after scheduling dates with the research participants.

The instrument used in the pre- and post-test was adapted from the study by $\mathrm{Cabral}$ and Oliveira ${ }^{(10)}$, considering the morbidity and mortality rates and the findings in the scientific literature on accidents taking place in nursery schools $^{(20-21)}$, and consisted of objective questions, divided into two blocks, the first referring to the characterization of participants and the second to knowledge about first aid, including: burns, cuts, fractures, choking/asphyxia, seizures, intoxication, dental trauma, venomous animals bite, fainting, cardiorespiratory arrest, electric shock, injury from a sharp object, hemorrhages, bites, and emergency telephone numbers. In 2018, a pilot study of the instrument was carried out with two early childhood education teachers from a neighboring municipality, who were not part of the study population. Based on it, adjustments were made in the writing of some questions to make them clearer and with accessible language.

The educational action was guided by the participatory methodology $\mathrm{y}^{(22)}$ and planned based on the demands emerging from the pre-test performed; thus, greater focus was given to themes related to cardiorespiratory arrest (CPA), choking or asphyxiation, and venomous animal bites, which had a lower percentage of correct answers in the pre-test; however, we sought to address all the themes presented in the pre-test to solve possible doubts. Therefore, classrooms provided by the schools and materials such as a presentation with images and videos were used, as well as a baby-sized doll and materials such as gauze and bandages for simulating first aid.

\section{Data Analysis and Treatment}

Data were organized in Excel spreadsheets and exported to the software Statistical Package for Social Sciences (SPSS Statistics), where they were analyzed using statistical techniques. The Shapiro-Wilk test for normality was performed, followed by the Wilcoxon test, due to data asymmetry. To compare the results of the pre- and post-test, grades were developed according to the number of correct answers for each participant, namely: excellent $\geq 14$ correct answers; good, from 11 to 13; fair, from 8 to 10; and poor, $\leq$ to 7 . The goal was that the participants reached a minimum of $70 \%$ correct answers in each question in the post-test, as this percentage is commonly used.

\section{ETHICAL Aspects}

The research followed the ethical recommendations of the National Health Council, according to Resolution $466 / 2012^{(23)}$, and was approved on September 11, 2018 by the Research Ethics Committee of the Universidade Federal de Santa Maria, with registration number 2.887.684. All participants who agreed to participate in the study signed an informed consent form.

\section{RESULTS}

Forty-five of the 52 teachers from four early childhood education schools in a municipality located in the center of the state of Rio Grande do Sul (RS) participated in the study. The participants are all women, and ages ranged from 26 to 65 years, with a median of 38 years and an interquartile range of 32.5 to 51.0 years.

As for training, 100\% had a degree in Pedagogy; of these, $88.9 \%$ had a degree only in Pedagogy and the others had other degrees. Regarding graduate studies, $60 \%$ have a graduate certificate, $13.3 \%$ a graduate certificate and a master's degree, $8.9 \%$ a master's degree, $2.2 \%$ have a graduate certificate, a master's degree and a $\mathrm{Ph} . \mathrm{D}$. degree, and the rest (15.6\%) of them do not have graduate studies.

Regarding time since graduation, there was a variation between three months and 32 years, with a median of 11 years and an interquartile range of 7.5 to 20.0 years. The time working in the schools where the study took place ranged from three months to 32 years, with a median of 3.5 years and an interquartile range of 1.35 to nine years. With regard to previous work, $26.7 \%$ of the participants worked in elementary school, $22.2 \%$ did not work in another level of education, $15.6 \%$ in early childhood education and elementary school, and the others in other levels of education (higher education, technical education, youth and adult education, and special educational needs).

As for the availability of the subject first aid in the undergraduation course of Pedagogy, $77.8 \%$ reported not having attended a course and $22.2 \%$ attended a discipline on the subject. Regarding extracurricular training related to first aid, $68.9 \%$ did not take it and $31.1 \%$ took a course on the subject.

Regarding the participants' experiences of witnessing first aid needs at school, 71.1\% said they had witnessed it and $28.9 \%$ said they had not had contact with situations requiring these actions. The most commonly experienced ones were cut or graze injury (46.66\%), nose bleeding (44.44\%), bite - from another child (40\%), choking or asphyxiation (24.44\%), fracture (20\%), and seizure (20\%). Based on the above, $100 \%$ of the participants recognized the importance of training teachers on acting in first aid.

By analyzing the results of the pre-test, it was possible to observe that the questions with the highest number of correct answers were about electric shock (100\%) and chemical poisoning (93.3\%). The questions about cardiopulmonary arrest (CPA) (13.3\%), choking or asphyxiation 
Table 1 - Percentage of correct answers in the pre- and post-test of early childhood education teachers - Santa Maria, RS, Brazil, 2018/2019.

\begin{tabular}{|c|c|c|c|c|c|}
\hline \multirow{3}{*}{ Question } & \multirow{3}{*}{ Question topic } & \multirow{2}{*}{\multicolumn{2}{|c|}{$\begin{array}{c}\text { Pretest } \\
\begin{array}{l}\text { Correct } \\
\text { answers }\end{array}\end{array}$}} & \multirow{2}{*}{\multicolumn{2}{|c|}{$\begin{array}{c}\text { Post-test } \\
\begin{array}{c}\text { Correct } \\
\text { answers }\end{array}\end{array}$}} \\
\hline & & & & & \\
\hline & & $\mathbf{N}$ & $\%$ & $\mathbf{N}$ & $\%$ \\
\hline Q1 & Burn & 41 & 91.1 & 41 & 91.1 \\
\hline Q2 & Cut or graze wound & 24 & 53.3 & 39 & 86.7 \\
\hline Q3 & Limb fracture or sprain & 28 & 62.2 & 29 & 64.4 \\
\hline Q4 & Choking & 12 & 26.7 & 26 & 57.8 \\
\hline Q5 & Nosebleed & 22 & 48.9 & 41 & 91.1 \\
\hline Q6 & Seizure attack & 37 & 82.2 & 45 & 100 \\
\hline Q7 & Chemical poisoning & 42 & 93.3 & 44 & 97.8 \\
\hline Q8 & Dental trauma & 37 & 82.2 & 41 & 91.1 \\
\hline Q9 & Venomous animal bite & 18 & 40 & 40 & 88.9 \\
\hline Q10 & Fainting & 35 & 77.8 & 45 & 100 \\
\hline Q11 & Emergency number & 29 & 64.4 & 36 & 80 \\
\hline Q12 & Sharp object injury & 39 & 86.7 & 43 & 95.6 \\
\hline Q13 & Electric shock & 45 & 100 & 45 & 100 \\
\hline Q14 & Hemorrhage & 23 & 51.1 & 40 & 88.9 \\
\hline Q15 & Cardiopulmonary arrest & 6 & 13.3 & 23 & 51.1 \\
\hline Q16 & Bite & 38 & 84.4 & 42 & 93.3 \\
\hline
\end{tabular}

Source: researcher data.

(26.7\%), and venomous animal bite (40\%) had a lower percentage. In the post-test, the questions with the highest number of correct answers were those about seizure attacks (100\%), fainting (100\%), and electric shock (100\%), and the questions with the lowest number of correct answers were about CRP (51.1\%), choking or asphyxiation (57.8\%), and limb fracture or sprain (64.4\%), as shown in Table 1.

With regard to grades, it is noted that in the pre-test, five participants had grade excellent and 17 participants had a grade good; in the post-test, 29 participants had an grade excellent and 16 good, as shown in Table 2.

Based on the data presented, it can be seen that there was an increase in the number of correct answers for the questions, with emphasis on the questions related to nasal bleeding (from 48.9 in the pre-test to $91.1 \%$ in the post-test), hemorrhages (from 51.1 in the pre-test to $88.9 \%$ in the post-test), cardiopulmonary arrest (from 13.3 in the pre-test to $51.1 \%$ in the post-test), and cut or graze injury (from $53.3 \%$ to $86.7 \%$ ). It is observed that there was an improvement in relation to the concepts, since in the post-test the good and excellent concepts showed a percentage increase and the fair and poor concepts had a zero percentage (Table 2).

It is also noticed that the previous experience of the participants who had first-aid situations at school induced them to make mistakes in the pre-test - in the behaviors to be carried out in situations of cut or graze wounds, nose bleeding, choking or asphyxiation, and fracture, as they did not reach $70 \%$ of correct answers - and to choose the
Table 2 - Distribution of early childhood education teachers, pre- and post-test - Santa Maria, RS, Brazil, 2018/2019.

\begin{tabular}{lcccc}
\hline \multirow{2}{*}{ Concept } & \multicolumn{2}{c}{ Pretest } & \multicolumn{2}{c}{ Post-test } \\
\cline { 2 - 5 } & $\mathrm{N}$ & $\%$ & $\mathrm{~N}$ & $\%$ \\
\hline Excellent & 5 & 11.1 & 29 & 35.6 \\
Good & 17 & 37.8 & 16 & 64.4 \\
Fair & 20 & 44.4 & 0 & 0 \\
Poor & 3 & 6.7 & 0 & 0 \\
\hline Total & $\mathbf{4 5}$ & $\mathbf{1 0 0 . 0}$ & $\mathbf{4 5}$ & $\mathbf{1 0 0 . 0}$ \\
\hline
\end{tabular}

Source: researcher data.

Table 3 - Wilcoxon test results - Santa Maria, RS, Brazil, 2018/2019.

\begin{tabular}{llcc}
\hline \multicolumn{1}{c}{ Statistical test } & N & Z & p \\
\hline Post-test - Pre-test & 45 & 5.17 & 0,045 \\
\hline Source: researcher data. & & &
\end{tabular}

Source: researcher data.

correct actions to be carried out in case of bites and seizures, achieving more than $70 \%$ of correctness. The theme related to electric shock is also highlighted, with no difference in the results, as both in the pre- and post-test there were 100\% of correct answers, and all participants chose the alternative that suggested turning off the power in the house when a child is being electrocuted by inserting a hairpin into an outlet.

Regarding the Wilcoxon test, performed in the software SPSS, there was an increase in the score from pre- to post-test by 5.17 points and the comparison of sums was significant with $\mathrm{p}=0,045$, Table 3 .

\section{DISCUSSION}

Educational actions on first aid for early childhood education teachers are consistent with the provisions of PSE, which aims at the permanent integration and articulation of education and health through actions of health promotion, prevention, and care ${ }^{(7)}$, and with the provisions of Law No.13.722, of October 4, 2018, which makes annual training and/or qualification on first aid basics to teachers of early childhood education in public and private primary education and child recreation institutions ${ }^{(15)}$ mandatory. Accordingly, it corroborates the National Policy for the Reduction of Morbidity and Mortality from Accidents and Violence, which aims to expand information to early childhood education teachers about appropriate behavior in cases that first aid actions are required ${ }^{(6)}$.

Based on the results, which showed a prevalence of the participation of women, it should be noted that women are the majority in Pedagogy fields of work. This has remained the same to this date, due to the social cultural process of recognizing women as people born to be educators, based on the association with their maternal role ${ }^{(24)}$. The same result is seen in other studies ${ }^{(13,17)}$. Regarding training, only $15.6 \%$ do not have a graduate degree; this characteristic is part of the profile of undergraduates of the Pedagogy course, as most professionals in this area have graduate degrees ${ }^{(25)}$. 
With regard to prior work in the area, $22.2 \%$ of teachers had not worked at other levels of education. According to Resolution No. 2, of July 1, 2015, teachers can work in different areas of knowledge, which may cover a specific and/or interdisciplinary field ${ }^{(26)}$. This resolution defines the national curriculum guidelines for initial training at higher education (undergraduate courses to become teachers, pedagogical training courses for undergraduates, and a second undergraduate course) and does not require first aid subjects in the course's syllabus.

As a result, it is evident that $77.8 \%$ of teachers did not attend courses on first aid during undergraduate courses. The same is shown in other studies, in which 10 out of 31 teachers claimed to have participated in a discipline on first aid in their undergraduate course, and six out of 10 teachers reported having first aid instructions in their training $^{(10,17)}$.

Likewise, continuing education is encouraged in Resolution No. 2, of July 1, 2015, which defines the national curriculum guidelines for initial and continuing education at higher level, for undergraduate and pedagogy courses. However, it does not mention the obligation to take extracurricular courses on first aid ${ }^{(26)}$. This fact is evident in the results obtained in this study, since only $31.1 \%$ of early childhood education teachers took a course on the subject. The study also shows that there is little demand for complementary courses on first aid, as seven of the 31 teachers in the study took this type of course ${ }^{(10)}$.

On the other hand, $71.1 \%$ of teachers said they had witnessed a situation requiring first aid and 100\% recognized the importance of first aid training for teachers, highlighting the significance of them knowing the correct way to provide this service. Similar results were presented in other studies ${ }^{(10,17)}$. It is necessary for teachers to understand that they can engage in decisive behaviors to save lives until the arrival of emergency care, and for that they need to be prepared on the subject ${ }^{(13)}$. Recognizing risk situations or intervening correctly in the first assistance makes a difference in the quality of the assistance provided and in the work of the health team ${ }^{(27)}$.

With regard to the previous experience of the participants who had a situation of first aid requirement at school, it is observed that in the pre-test, in some situations, there were errors related to the conduct to be adopted, such as in cut or graze wounds, nosebleeds, choking or asphyxiation, and fracture, and in other situations, such as bites and seizures, there were more right choices for the appropriate behavior. This result differs from that presented in a study carried out with 110 preschool teachers, which showed no significant difference in the score related to the participants' previous experience in relation to first aid ${ }^{(14)}$. It also differs from the result presented in a study carried out with 194 preschool teachers in Ethiopia, in which it was found that the experience with children who need first aid was positively associated with the attitude towards first aid ${ }^{(28)}$.

The results of this study showed that the situations commonly experienced were similar to those presented in another study, in which the most reported cases referred to nose bleeding, wounds, fractures, and bites ${ }^{(10)}$. As for electric shock, the result of this study differs from that presented by another author who reports that out of 200 teachers, the majority (85.2\%) gave wrong answers to the question concerning first aid in a child receiving an electric shock ${ }^{(29)}$.

Regarding the results of the pre-test, there is disagreement with what was shown in a study presenting a higher percentage of correct answers in the questions about CPA, trauma, seizures, drowning and burns, and a lower rate of correct answers in those about hemorrhage, fainting, transport of accidents victims, and immobilization. Although the studies present some different themes, it is noted that there is disagreement regarding the number of correct answers on questions with similar themes. However, in both, there was an increase in the percentage of correct answers from pre- to post-test, showing that health education activities provided participants with reflective critical thinking, considering the local reality, for the construction of new knowledge ${ }^{(9)}$.

From this perspective, when considering the school environment, the need to provide training on first aid for early childhood education teachers, and the effectiveness of health education actions on the topic, the importance of carrying out PSE on this topic is highlighted. Authors report that the PSE is relevant, but first aid at school shall be contemplated, with the training of teachers ${ }^{(13)}$.

Nurses are responsible for carrying out the situational diagnosis of the subjects and determinants involved, planning the health education action, implementing and evaluating it, as they have a holistic view and critical-reflective reasoning ${ }^{(13)}$. They also have teaching as one of their competencies and uses it as an instrument to generate changes in the population's health profile, through the promotion and prevention of diseases and injuries, thus being able to contribute to the teaching of first aid in school settings ${ }^{(10)}$. Considering these aspects, nursing can significantly contribute to health education on first aid for early childhood education teachers. Conducting this study only with teachers working at EMEIs in a specific municipality is a limitation of the study. Another limitation is the fact that early childhood education teachers from private educational institutions were not included in this study.

\section{CONCLUSION}

Carrying out educational actions on first aid increases the knowledge of early childhood education teachers on the subject, with nurses having an important role as health educators, especially in programs such as PSE. This confirms hypothesis one, that the educational action changed the knowledge of early childhood education teachers about first aid in school settings, and refutes hypothesis zero, which states that the educational action did not change the knowledge of early childhood education teachers about first aid in the school environment. It should be noted that educational actions on first aid are a form 
of training and/or qualification on the subject, and shall be carried out annually as provided for in Law No. 13.722 of 2018.

In the context of health education, nursing work is highlighted, as it has a holistic view and critical-reflective reasoning, being in charge of planning, implementing, and evaluating health education actions based on the diagnosis of the situation and the subjects involved in the process. Thus, it can significantly contribute to the teaching of first aid for early childhood education teachers, making this process unique, as the peculiarities arising from the diagnosis performed are considered.

\section{RESUMO}

Objetivo: Verificar o conhecimento dos professores da educação infantil sobre os primeiros socorros antes e após a participação na ação educativa. Método: pesquisa quantitativa com delineamento quase-experimental do tipo pré e pós-teste, realizado com 45 professores de quatros escolas de educação infantil. Utilizou-se para coleta de dados um instrumento com questões referentes à caracterização dos participantes e ao conhecimento sobre os primeiros socorros. Os dados foram analisados por meio de técnicas de estatística, sendo realizado o teste de Shapiro Wilk e de Wilcoxon. Resultados: houve aumento no número de acertos das questões e melhora em relação aos conceitos, com aumento na pontuação do pré para o pós-teste em 5,17 pontos e com a comparação das somas significativa. Conclusão: a realização de ações educativas sobre primeiros socorros aumenta o conhecimento de professores da educação infantil sobre o tema e os enfermeiros possuem destaque na atuação como educadores em saúde.

\section{DESCRITORES}

Primeiros Socorros; Educação Infantil; Enfermagem; Educação em Saúde.

\section{RESUMEN}

Objetivo: Averiguar el conocimiento de los profesores de la educación infantil sobre los primeros auxilios antes y después de la participación en la acción educativa. Método: investigación cuantitativa con delineación casi experimental del tipo pre y post-test, realizado con 45 profesores de cuatro escuelas de educación infantil. Se utilizó para recolección de datos un instrumento con cuestiones referentes a la caracterización de los participantes y al conocimiento sobre los primeros auxilios. Los datos fueron analizados por medio de técnicas de estadística, por lo que se realizaron el test de Shapiro Wilk y de Wilcoxon. Resultados: hubo aumento en el número de cuestiones correctas y mejora en relación a los conceptos, con aumento en la puntuación del pre para el post-test en 5,17 puntos y con la comparación de las sumas significativa. Conclusión: la realización de acciones educativas sobre primeros auxilios aumenta el conocimiento de profesores de la educación infantil sobre el tema y los enfermeros poseen destaque en la actuación como educadores en Salud.

\section{DESCRIPTORES}

Primeros auxilios; Crianza del Niño; Enfermería; Educación en Salud.

\section{REFERENCES}

1. Brasil. Ministério da Cidadania. A primeira infância [Internet]. Brasília; c2016 [cited 2020 Dec 16]. Available from: http://mds.gov.br/ assuntos/crianca-feliz/crianca-feliz/a-primeira-infancia\#wrapper.

2. Brasil. Ministério da Educação. Base Nacional Comum Curricular [Internet]. Brasília; c1996 [cited 2021 Apr 14]. Available from: http:// basenacionalcomum.mec.gov.br/.

3. Brasil. Ministério da Saúde. Sistema de Informações sobre Mortalidade [Internet]. Brasília; c1991 [cited 2020 Dec 15]. Available from: http://tabnet.datasus.gov.br/cgi/tabcgi.exe?sim/cnv/obt10uf.def.

4. Oliveira JS, Constâncio TOS, Santos ISC, Nery AA. Deaths due to external causes related to work. J Nurs UFPE on line. 2019;13:e237870. DOI: https://doi.org/10.5205/1981-8963.2019.237870.

5. Filócomo FRF, Harada MJCS, Mantovani R, Ohara CVS. Profile of accidents in children and adolescents receiving care at a public hospital. Acta Paul Enferm. 2017;30(3):287-94. DOI: https://doi.org/10.1590/1982-0194201700044.

6. Brasil. Ministério da Saúde. Portaria MS/GM n. 737, de 16 de maio de 2001. Política nacional de redução da morbimortalidade por acidentes e violências [Internet]. Brasília; 2001 [cited 2020 Dec 20]. Available from: http://bvsms.saude.gov.br/bvs/publicacoes/politica_ reducao_morbimortalidade_acidentes_2ed.pdf.

7. Brasil. Ministério da Educação. Programa Saúde na Escola Brasília [Internet]. Brasília; c2018 [cited 2020 Dec 21]. Available from: http:// portal.mec.gov.br/expansao-da-rede-federal/194-secretarias-112877938/secad-educacao-continuada-223369541/14578-programa-saudenas-escolas.

8. Brasil. Ministério da Saúde. Portaria n. 1.130, de 5 de agosto de 2015. Institui a Política Nacional de Atenção Integral à Saúde da Criança (PNAISC) no âmbito do Sistema Único de Saúde (SUS) [Internet]. Brasília; 2015 [cited 2020 Dec 16]. Available from: http://bvsms.saude. gov.br/bvs/saudelegis/gm/2015/prt1130_05_08_2015.html.

9. Pereira KC, Paulino JR, Saltarelli RMF, Carvalho AMP, Santos RB, Silveira TVL, et al. The construction of knowledge about the prevention of accidents and first aid by the lay public. R. Enferm. Cent. O. Min. 2015 [cited 2021 Apr 12];5(1):1478-85. Available from: http://www. seer.ufsj.edu.br/index.php/recom/article/view/456/837.

10. Cabral EV, Oliveira MFA. First aid at school: teacher knowledge. Revista Práxis [Internet]. 2019 [cited 2021 Apr 12];11(22):97-106. Available from: http://revistas.unifoa.edu.br/index.php/praxis/article/view/712/2495.

11. Calandrim LF, Santos AB, Oliveira LR, Massaro LG, Vedovato CA, Boaventura AP. First aid at school: teacher and staff training. Rev Rene. 2017;18(3):292-9. DOI: http://doi.org/10.15253/2175-6783.2017000300002. 
12. Leite HSN, Bonfim CR, Formiga HJB, Ferreira AM, Barbosa ABA, Martins ENX. First aid at school: knowledge of the team that composes educational management. Temas em Saúde. 2018;(FIP 2018):290-312.

13. Galindo Neto NM, Carvalho GCN, Castro RCMB, Caetano JÁ, Santos ECB, Silva TM, et al. Teachers' experiences about first aid at school. Rev Bras Enferm. 2018;71(suppl 4):1775-82. DOI: http://dx.doi.org/10.1590/0034-7167-2017-0715.

14. Sönmez Y, Uskun E, Pehlivan A. Knowledge levels of pre-school teachers related with basic first-aid practices, Isparta sample. Turk Pediatri Ars. 2014;49(3):238-46. DOI: http://dx.doi.org/10.5152/tpa.2014.1581.

15. Brasil. Lei n. 13.722, de 4 de outubro de 2018. Torna obrigatória a capacitação em noções básicas de primeiros socorros de professores e funcionários de estabelecimentos de ensino públicos e privados de educação básica e de estabelecimentos de recreação infantil [Internet]. Brasília; 2018 [cited 2020 Dec 20]. Available from: http://www.planalto.gov.br/ccivil_03/_ato2015-2018/2018/lei/L13722.htm.

16. Ferreira NLM, Medeiros LSM, Bonfim CR, Barbosa ABA, Martins ENX, Ferreira AM. First aid in early childhood education. Temas em Saúde. 2018;(FIP 2018):18-39.

17. Carmo HO, Souza RCA, Araújo CLO, Francisco AG. Attitudes of teachers of child education in school accident situation. Revista de Enfermagem do Centro-Oeste Mineiro. 2017;7:e1457. DOI: https://doi.org/10.19175/recom.v7i0.1457.

18. Brasil. Lei n. 7.498, de 25 de junho de 1986. Dispõe sobre a regulamentação do exercício da Enfermagem e dá outras providências [Internet]. Brasília; 1986 [cited 2020 Dec 20]. Available from: http://www.planalto.gov.br/ccivil_03/leis/l7498.htm.

19. Oliveira RS, Moraes SH, Portugal MEG, Silva FB. The nurse's activities in schools: challenges and perspectives. Rev Gestão \& Saúde [Internet]. 2018 [cited 2021 Apr 14];18(2):10-22. Available from: http://www.herrero.com.br/files/revista/fileb861209a53556557cd850 a74126688a8.pdf.

20. Costa SNG, Silva JMM da, Freitas BHBM, Reis AFC. Child accidents: knowledge and perception of daycare educators. J Nurs UFPE on line, 2017;11(10):3845-52. DOI: https://doi.org/10.5205/reuol.12834-30982-1-SM.1110201719.

21. Coelho LCA, Silva LRC. Formação docente, educação infantil e prevenção de acidentes. I Sem. Int. de Rep. Sociais, Subjetividade e Educação [Internet]. 2011 [cited 2021 Apr 14];7922-33. Available from: https://educere.bruc.com.br/CD2011/pdf/5086_3438.pdf.

22. Brasil. Ministério da Saúde. Ideias e dicas para o desenvolvimento de processos participativos em saúde [Internet]. Brasília; 2016 [cited 2020 Dec 22]. Available from: https://antigo.saude.gov.br/images/pdf/2016/novembro/10/Ideias-Dicas-P-Participativos-2016-10-04-finalfinal.pdf.

23. Brasil. Ministério da Saúde. Resolução n. 466, de 12 de dezembro de 2012 [Internet]. Brasília; 2012 [cited 2020 Dez 20]. Available from: https://www.inca.gov.br/sites/ufu.sti.inca.local/files//media/document//resolucao-cns-466-12.pdf.

24. Lira ACM, Bernardim GP. O profissional do gênero masculino na educação infantil: com a palavra, pais e professores. Poiésis. 2015;9(15):80-97. DOI: http://dx.doi.org/10.19177/prppge.v9e15201580-97.

25. Barreto MP, Prestes Z, Estevam LG. Perfil de pedagogos formados pela faculdade de educação da universidade federal fluminense. RevistAleph. 2017;30:7-25. DOI: http://dx.doi.org/10.22409/revistaleph.v0i0.39208.

26. Brasil. Ministério da Educação. Resolução n. 2, de $1^{\circ}$ de julho de 2015. Define as Diretrizes Curriculares Nacionais para a formação inicial em nível superior (cursos de licenciatura, cursos de formação pedagógica para graduados e cursos de segunda licenciatura) e para a formação continuada [Internet]. Brasília; 2015 [cited 2020 Dec 20]. Available from: http://portal.mec.gov.br/docman/agosto-2017pdf/70431-res-cne-cp-002-03072015-pdf/file.

27. Dantas RAN, Dantas DV, Silva IRN, Araújo NM, Laurentino AMA, Nunes HMA, et al. Approach to first aid in school: children, teenagers and teachers learning to save lives. Enfermagem Brasil. 2018;17(3):259-65. DOI: http://dx.doi.org/10.33233/eb.v17i3.1186.

28. Ganfure G, Ameya G, Tamirat A, Lencha B, Bikila D. First aid knowledge, attitude, practice, and associated factors among kindergarten teachers of Lideta sub-city Addis Ababa, Ethiopia. PLoS One. 2018;13(3):e0194263. DOI: https://doi.org/10.1371/journal.pone.019426.

29. Adib-Hajbaghery M, Kamrava Z. Iranian teachers' knowledge about first aid in the school environment. Chin J Traumatol. 2019; $22(4): 240-5$. DOI: http://dx.doi.org/10.1016/j.cjtee.2019.02.003. 